\title{
ANALYTICAL METHOD DEVELOPMENT AND VALIDATION OF ESTIMATION OF DENAVERINE HYDROCHLORIDE IN BULK AND INJECTABLE PHARMACEUTICAL DOSAGE FORM BY UV- SPECTROPHOTOMETRIC METHOD
}

\author{
Dr. G. Krishnamoorthy \\ Head, Department of Pharmaceutical Analysis, Periyar College of Pharmaceutical Sciences, \\ Tiruchirappalli, Tamil Nadu, India. \\ E-Mail.Id:vkm292011@hotmail.com \\ Mr. J. Ijaz Ahamed \\ Post graduate student, Department of Pharmaceutical Analysis, Periyar College of \\ Pharmaceutical Sciences, Tiruchirappalli, Tamil Nadu, India. \\ E-Mail.Id:ijazvkr@gmail.com \\ Miss. S. Ramya \\ Post graduate student, Department of Pharmaceutical Analysis. Periyar College of \\ Pharmaceutical Sciences, Tiruchirappalli. Tamil Nadu. India. \\ E-Mail.Id: ramyashanthi225@gmail.com

\section{Mr. M. Sivaganesh} \\ Post graduate student, Department of Pharmaceutical Analysis, Periyar \\ College of Pharmaceutical Sciences, Tiruchirappalli, Tamil Nadu, India. \\ E-Mail.Id: sivaganesh2761@gmail.com

\section{Dr. R. Senthamarai}

Principal. Department of Pharmacognosy, Periyar College of Pharmaceutical Sciences, Tiruchirappalli, Tamil Nadu, India.

E-Mail.Id: periyarcps@gmail.com

\section{Corresponding Author:}

Dr. G. Krishnamoorthy, Head, Department of Pharmaceutical Analysis, Periyar College of Pharmaceutical Sciences, Tiruchirappalli, Tamil Nadu, India.

E-Mail.Id:vkm292011@hotmail.com Ph:9843482447 


\section{Abstract:}

It has been accomplished the development of a simple and rapid $U V$ spectrophotometric method to estimate for the evaluation of Denaverine hydrochloride, which is used in the treatment of antispasmodic drug in Veterinary medicine. The present study describes the method developed a simple and reproducible. UV-Visible spectrophotometric method for the quantitative determination of Denaverine hydrochloride. A UV-Visible spectrophotometric method with $1 \mathrm{~cm}$ quartz cells and distilled Methanol solvent was employed. The proposed method was successfully applied for the estimation of Denaverine hydrochloride in commercial pharmaceutical preparation with UV detection at $221 \mathrm{~nm}$. It obey's Beer law in the concentration range of 3 to $15 \mu \mathrm{g} / \mathrm{mL}$ having correlation coefficient of 0.9997, Percentage recovery (100.0\%). In terms of linearity, precision, accuracy, recovery, limit of detection (LOD), and limit of quantitation (LOQ), the developed technique was within limit as per ICH guidelines.

Key words: Denaverine hydrochloride, Absorbance Maxima, UV Spectrophotometry.

\section{INTRODUCTION}

Denaverine hydrochloride ${ }^{[1-6]}$ is a muscle relaxant. It was developed and patented in Germany in 1974. Under the brand name Sensiblex, Denaverine hydrochloride is used in Veterinary medicine as a muscle relaxant for the myometrium of cows and dogs during parturition. Now, the drug is in trial with human plasma to treat urogenital and gastrointestinal spasms under the brand Spasmalgan.

Denaverine hydrochloride, is a neurotropic-musculotropic spasmolytic with analgesic effect. It's used to treat gastrointestinal and urogenital smooth muscle spasms, as well as postoperative abdominal pain and obstetrics. Despite the fact that denaverine hydrochloride has been used successfully in therapy for over 30 years, there was little information on its biotransformation in humans.

\section{Structure}<smiles>CCC(CC)COC(C(=O)OCCN(C)C)(c1ccccc1)c1ccccc1</smiles>

Fig. 1 Chemical Structure of Denaverine hydrochloride

Chemical name: 2-dimethylaminoethyl2-(2-ethylbutoxy)-2,2diphenylacetate hydrochloride 


\section{Mechanisms of Action}

Denaverine inhibits the enzyme phosphodiesterase. A phosphodiesterase inhibitor is a drug that inhibits the inactivation of the intracellular second messengers cyclic Adenosine MonoPhosphate (cAMP) and cyclic Guanosine MonoPhosphate (cGMP) by one or more of the five subtypes of the enzyme PhosphoDiEsterase (PDE). It has anticholinergic properties. Anticholinergics (anticholinergic agents) are a class of drugs that prevent the neurotransmitter acetylcholine (ACh) from acting at synapses in the central and peripheral nervous systems.

\section{MATERIALS AND METHODS:}

Instrument: A Shimadzu UV-1600 UV/VIS Spectrophotometer was used with $1 \mathrm{~cm}$ matched quartz cell.

\section{Materials and Reagents:}

All the chemicals used were of analytical grade. An analytically pure sample of Denaverine hydrochloride was procured as gift sample from HITECH LABORATORY,Chennai.

\section{Preparation of Solution Standard Solution Preparation}

Accurately weighed and transfered $10 \mathrm{mg}$ of Denaverine working standard into a 10 $\mathrm{mL}$ volumetric flask. About $7 \mathrm{~mL}$ of methanol was added and sonicate to dissolve it completely. Then the solution was made volume up to the mark with the same solvent (1000 $\mu \mathrm{g} / \mathrm{mL}$ ). Further $1.0 \mathrm{~mL}$ of the Denaverine stock solution was pipette out into a $10 \mathrm{~mL}$ volumetric flask and dilute up to the mark with solvent $(100 \mu \mathrm{g} / \mathrm{mL})$. Further $0.9 \mathrm{~mL}$ of the Denaverine stock solution was pipette out into a $10 \mathrm{~mL}$ volumetric flask and dilute up to the mark with solvent $(9 \mu \mathrm{g} / \mathrm{mL})$.

\section{Sample Solution Preparation}

$0.25 \mathrm{~mL}$ of injection (Sensiblex $40 \mathrm{mg} / \mathrm{mL}$ ) was measured accurately and transfered the sample (equivalent to $10 \mathrm{mg}$ of Denaverine hydrochloride) into a $10 \mathrm{~mL}$ volumetric flask. $7 \mathrm{~mL}$ of methanol was added and sonicate to dissolve it completely. Then it was made volume up to the mark with same solvent $(1000 \mu \mathrm{g} / \mathrm{mL})$. The solution was mixed well and filter through $0.45 \mu \mathrm{m}$ filter. Further pipette $1 \mathrm{~mL}$ of the Denaverine solution into a $10 \mathrm{~mL}$ volumetric flask and dilute up to the mark with solvent $(100 \mu \mathrm{g} / \mathrm{mL})$. Further pipette $0.9 \mathrm{~mL}$ of the Denaverine stock solution into a $10 \mathrm{~mL}$ volumetric flask and dilute up to the mark with solvent $(9 \mu \mathrm{g} / \mathrm{mL})$. The sample solution $(9 \mu \mathrm{g} / \mathrm{mL})$ absorbance was measured against blank at $221 \mathrm{~nm}$. Percentage purity was calculated by using the following formula.

$$
\text { Assay } \%=\frac{\text { AT }}{\mathrm{AS}} \times \frac{\mathrm{WS}}{\mathrm{DS}} \times \frac{\mathrm{DT}}{\mathrm{WT}} \times \frac{\mathrm{P}}{100} \times \frac{\text { Avg.Wt }}{\text { Label Claim }} \times 100
$$




\section{Method development and validation}

\section{Linearity:}

From the stock solution, the aliquots of stock solution of Denaverine $(1000 \mu \mathrm{g} / \mathrm{mL})$ further dilution make up to $(0.3$ to $1.5 \mathrm{~mL}$ of $1000 \mu \mathrm{g} / \mathrm{mL})$ and transferred in to $100 \mathrm{~mL}$ volumetric flask and made up to the mark with solvent. The absorbance of the solution of different concentration were measured at $221 \mathrm{~nm}$ against blank. The calibration curve was plotted using Concentration Vs Absorbance. The curve obtained was linear with concentration range $3-15 \mu \mathrm{g} / \mathrm{mL}$.

\section{Recovery:}

$0.25 \mathrm{~mL}$ of injection (Sensiblex $40 \mathrm{mg} / \mathrm{mL}$ ) was measured accurately and transferred the sample (equivalent to $10 \mathrm{mg}$ of Denaverine hydrochloride) into three separate $10 \mathrm{~mL}$ volumetric flask. Then $5 \mathrm{mg}, 10 \mathrm{mg}$ and $15 \mathrm{mg}(50 \%, 100 \%, 150 \%)$ of standard were accurately weighed and added. $7 \mathrm{~mL}$ of methanol was added and sonicate to dissolve it completely. Then the solution was made volume up to the mark with the same solvent. 0.9 $\mathrm{mL}$ was pipette out from each flask and transferred to separate $100 \mathrm{~mL}$ volumetric flask. Then the solution was made volume up to the mark with the same solvent. Absorbance was measured at $221 \mathrm{~nm}$ against blank. The amount of drug recovered was calculated by using slope and intercept values.

\section{Precision:}

Repeatability and intermediate precision studies were done to the precision of the method. Repeatability studies were done by consequently measuring the absorbance of standard solution $(9 \mu \mathrm{g} / \mathrm{mL})$. These solutions were prepared in duplicate and absorbance were measured at $221 \mathrm{~nm}$ against blank and calculate the \% RSD.

\section{Limit of Detection (LOD) and Limit of Quantitation (LOQ)}

The LOD and LOQ were estimated from the set of s calibration curves used to determine method linearity.

$\mathrm{LOD}=3.3 \sigma / \mathrm{S}$ and $\mathrm{LOQ}=10^{*} \sigma / \mathrm{S}$

Where, $\sigma=$ the standard deviation of $y$-intercepts of regression lines.

$\mathrm{S}$ the slope of the calibration curve.

\section{RESULTS AND DISCUSSION}

- $\lambda$ Max was observed at $221 \mathrm{~nm}$

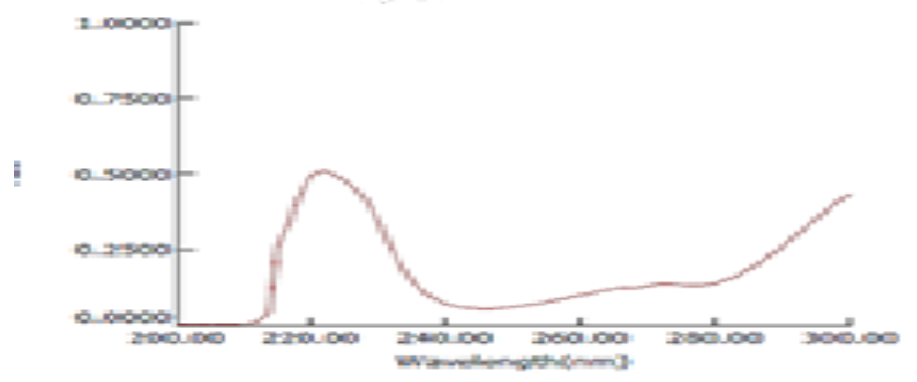

Fig. 2 Spectrum of Denaverine hydrochloride 


\section{Linearity:}

The Linearity for Denaverine hydrochloride was found to be concentration range 3-15 $\mu \mathrm{g} / \mathrm{mL}$ with Correlation Coefficient 0.9997. LOD and LOQ were found to be $0.216 \mu \mathrm{g} / \mathrm{mL}$ and $0.655 \mu \mathrm{g} / \mathrm{mL}$. Calibration data and \%RSD is shown in table 1 and curve is shown in figure 8 .

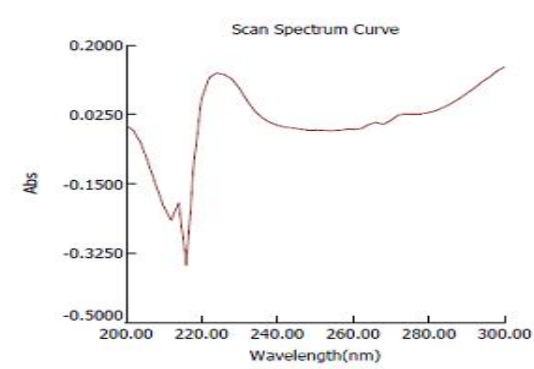

Fig. 3 Linearity Spectrum $(3 \mu \mathrm{g} / \mathrm{mL})$

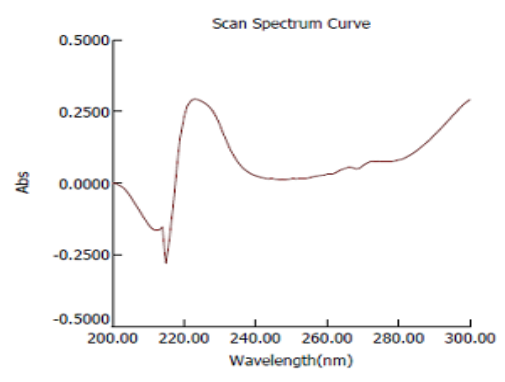

Fig. 4 Linearity Spectrum $(6 \mu \mathrm{g} / \mathrm{mL})$

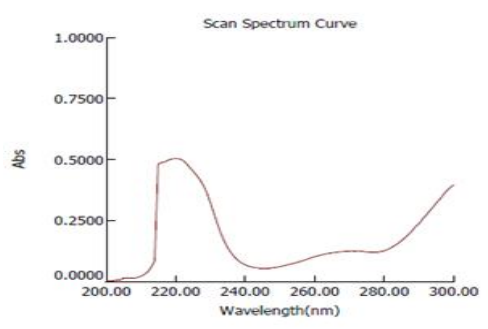

Fig. 5 Linearity $(9 \mu \mathrm{g} / \mathrm{mL})$

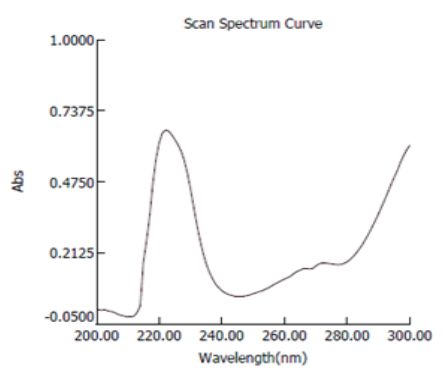

Fig. 6 Linearity $(12 \mu \mathrm{g} / \mathrm{mL})$

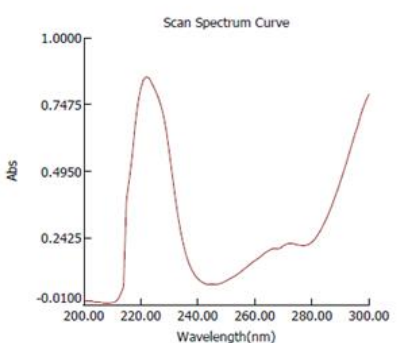

Fig. 7 Linearity $(15 \mu \mathrm{g} / \mathrm{mL})$

Table. 1 Results of Linearity

\begin{tabular}{|c|c|c|c|c|c|c|c|}
\hline S. No & Concentration & $\begin{array}{c}\text { Average } \\
\text { Absorbance }\end{array}$ & $\begin{array}{l}\text { Correlation } \\
\text { Coefficient }\end{array}$ & LOD & LOQ & Slope & Intercept \\
\hline 1 & $3 \mu \mathrm{g} / \mathrm{mL}$ & 0.155 & \multirow{5}{*}{0.9997} & \multirow{5}{*}{0.216} & \multirow{5}{*}{0.655} & \multirow{5}{*}{0.056} & \multirow{5}{*}{-0.007} \\
\hline 2 & $6 \mu \mathrm{g} / \mathrm{mL}$ & 0.328 & & & & & \\
\hline 3 & $9 \mu \mathrm{g} / \mathrm{mL}$ & 0.495 & & & & & \\
\hline 4 & $12 \mu \mathrm{g} / \mathrm{mL}$ & 0.663 & & & & & \\
\hline 5 & $15 \mu \mathrm{g} / \mathrm{mL}$ & 0.840 & & & & & \\
\hline
\end{tabular}




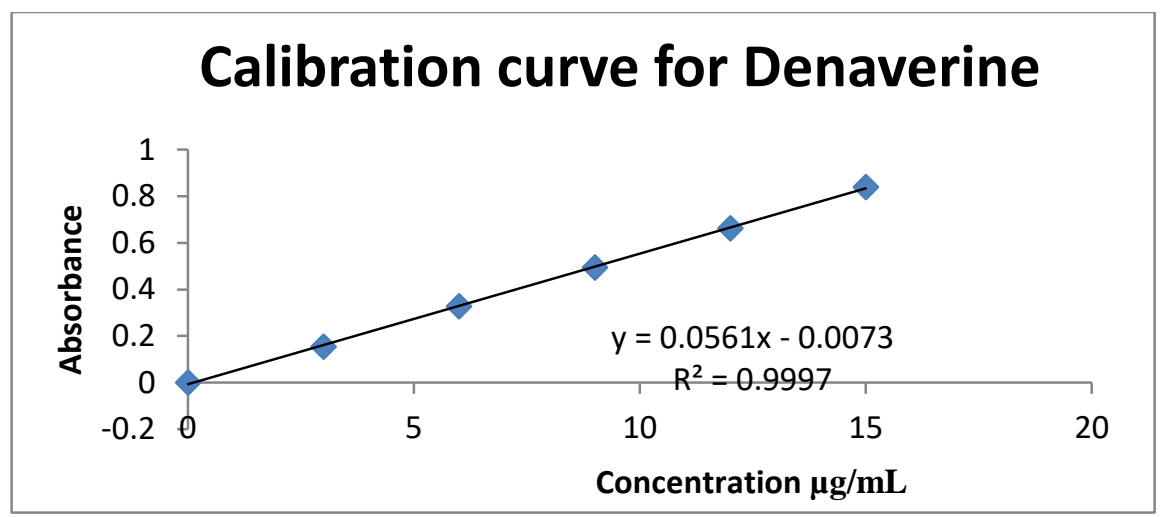

Fig. 8 Calibration curve for Denaverine

\section{Quantification of Formulation (Assay)}

The percentage of Denaverine in marketed formulation (Injection) was calculated from the calibration curve of Denaverine. \%Assay was found to be $99.95 \%$ as shown in Table 2

Table. 2 Results of Quantification of formulation (Assay)

\begin{tabular}{|l|l|l|l|l|l|l|}
\hline S.No & $\begin{array}{l}\text { Standard } \\
\text { Absorbance }\end{array}$ & $\begin{array}{l}\text { Sample } \\
\text { Absorbance }\end{array}$ & $\begin{array}{l}\text { Percentage } \\
\text { purity (\%) }\end{array}$ & $\begin{array}{l}\text { Average } \\
\text { Percentage } \\
(\%)\end{array}$ & SD & \%RSD \\
\hline 1 & 0.495 & 0.490 & 98.98 & & & \\
2 & 0.482 & 0.485 & 100.62 & & & \\
3 & 0.484 & 0.488 & 100.82 & 99.95 & 0.7610 & 0.7613 \\
4 & 0.480 & 0.481 & 99.79 & & & \\
5 & 0.470 & 0.468 & 99.57 & & & \\
\hline
\end{tabular}

mean of five readings.

\section{Recovery:}

The percentage recovery study for Denaverine hydrochloride was found to be 98.8-100.53.
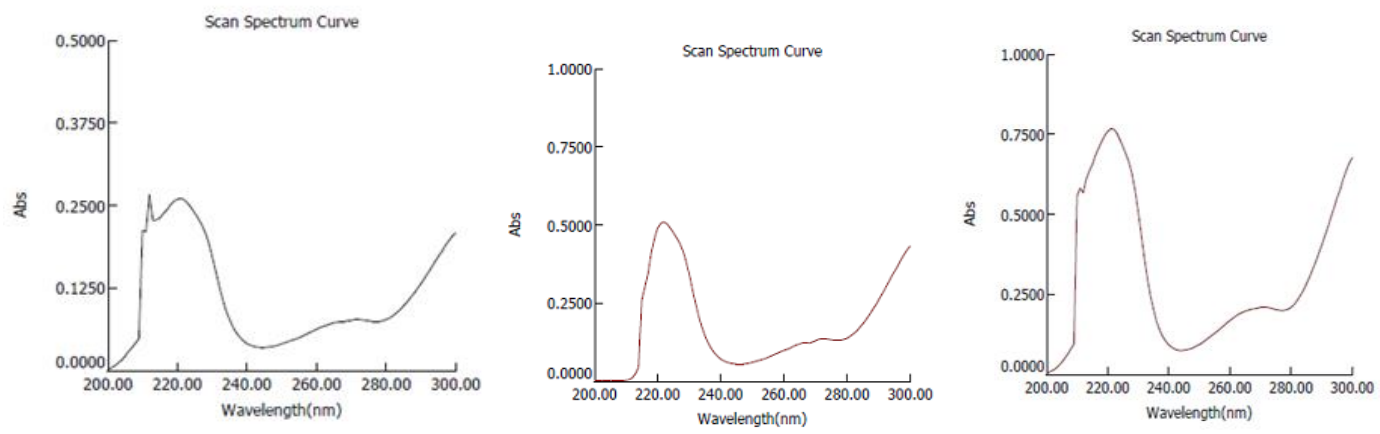

Fig. 8 Recovery Spectrum (50\%) Fig. 9 Recovery Spectrum (100\%) Fig. 10 Recovery Spectrum (150\%) 
Table. 3 Results of Recovery Data

\begin{tabular}{|c|c|c|c|c|c|}
\hline $\begin{array}{c}\text { \% } \\
\text { Concentration }\end{array}$ & Absorbance & $\begin{array}{c}\text { Amount } \\
\text { Added } \\
(\mathbf{m g})\end{array}$ & $\begin{array}{c}\text { Amount } \\
\text { Found } \\
(\mathbf{m g})\end{array}$ & \% Recovery & $\begin{array}{c}\text { Mean } \\
\text { Recovery }\end{array}$ \\
\hline $50 \%$ & 0.261 & 5.1 & 5.12 & $100.53 \%$ & \multirow{2}{*}{$100.0 \%$} \\
\cline { 1 - 4 } $100 \%$ & 0.508 & 10.1 & 9.98 & $98.8 \%$ & \\
\hline $150 \%$ & 0.769 & 15.0 & 15.10 & $100.7 \%$ & \\
\hline
\end{tabular}

"mean of three readings.

Precision:

$\%$ RSD was found to be 0.16

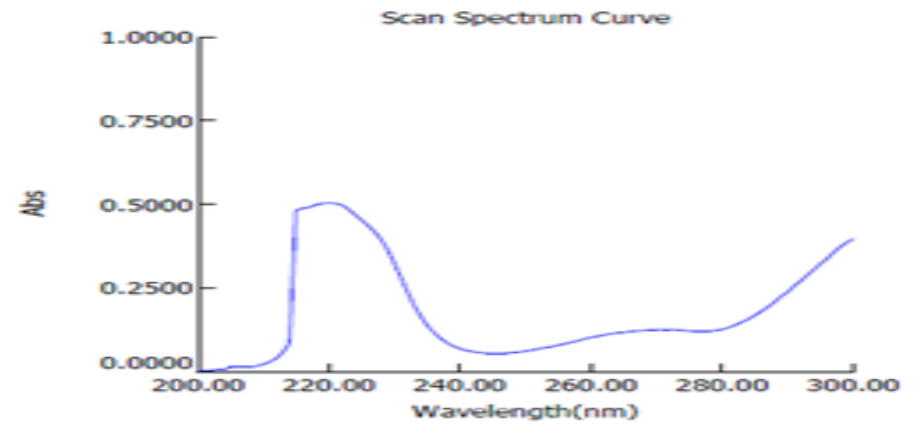

Fig. 11 Precision

Table. 4 Results of Precision Data

\begin{tabular}{|c|c|c|c|c|}
\hline S. No & Absorbance & Average Absorbance & SD & \% RSD \\
\hline 1 & 0.511 & & & \\
\hline 2 & 0.511 & 0.5118 & 0.0008 & 0.16 \\
\hline 3 & 0.512 & & & \\
\hline 4 & 0.512 & & & \\
\hline 5 & 0.513 & & & \\
\hline
\end{tabular}

*mean of five readings.

Intermediate precision:

$\%$ RSD was found to be 0.222

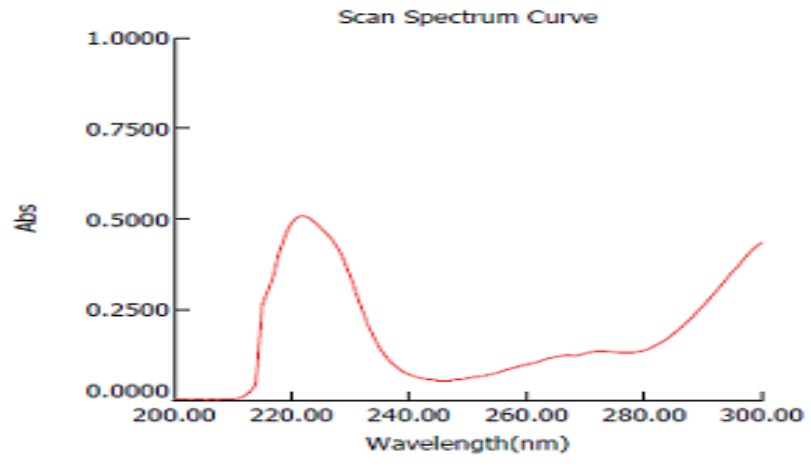

Fig. 12 Intermediate Precision Spectrum 
Table. 5 Results of Intermediate Precision Data

\begin{tabular}{|c|c|c|c|c|}
\hline S. No & Absorbance & Average Absorbance & SD & \% RSD \\
\hline 1 & 0.510 & & & \\
\hline 2 & 0.511 & 0.511 & 0.0011 & 0.222 \\
\hline 3 & 0.513 & & & \\
\hline 4 & 0.511 & & & \\
\hline 5 & 0.512 & & & \\
\hline
\end{tabular}

"mean of five readings.

\section{Conclusion}

The developed method was found to be simple, sensitive, accurate, precise, reproducible, and can be used for routine quality control analysis of Denaverine $\mathrm{Hcl}$ in bulk and pharmaceutical formulation.

\section{ACKNOWLEDGEMENTS}

The authors are thankful to the Founder Chairperson Dr. K. Veeramani of Periyar College Pharmaceutical Sciences, Trichy for providing necessary facilities

\section{REFERENCES}

[1] H. Huller,W. Scheler, E. Schulz, Acta Biol. Med. German. 12 (1964) 682.

[2] H. Huller, W. Scheler, H. Oberender, R. Peters, Acta Biol. Med. German.

22 (1969) 751.

[3] H. H“uller, Zbl. Pharmaz. 109 (1970) 115.

[4] V. Bredow, Zbl. Gynakol. 114 (1992) 551.

[5] E. Neumayer, Medicamentum 16 (1975) 264.

[6] B. Vesper, Medicamentum 12 (1971) 335. 